\title{
Influence of Tourism Development and Community Participation Factors on Opportunity of Gashaka Gumti National Park
}

\author{
${ }^{1,2}$ Kanati Madaki, ${ }^{1}$ Tonga Ak Noweg, ${ }^{1}$ Alexender Kiew Anak Sayok, ${ }^{1}$ Wong Swee Kiong, ${ }^{3}$ Isaac John Umaru \\ ${ }^{1}$ Institute of Biodiversity and Environmental Conservation, Universiti Malaysia Sarawak \\ ${ }^{2}$ Department of Hospitality Management and Tourism, Faculty of Agric and Life Sciences. Federal University Wukari, Nigeria \\ ${ }^{3}$ Department of Biochemistry, Federal University Wukari Taraba State.
}

\begin{abstract}
National parks are storehouse for wildlife and habitat and endowed with potentials. Although local community participation and tourism development can enhance the potentials of national park, identifying the significant factors influencing outcomes of maximizing opportunity of the Gashaka Gumti National Parks is important. Based on the backwards selection method of community support for tourism development, help to local community, tourism development bring job opportunity and community conservation initiative significantly contributes to the likelihood of maximizing opportunity of Gashaka Gumti National in conserving biodiversity. Thus it can be concluded that local community involvement and tourism development are more likely to impact biodiversity conservation in Gashaka Gumti national Parks than strict conservation.
\end{abstract}

Keywords:- Biodiversity, tourism, Gashaka Gumti, National Park. Local community.

\section{INTRODUCTION}

The growing number of national park has gained a global attention to ascertain their current status in conserving diversity and management (Kolahi et al., 2013; Schulze et al., 2017) to exploit opportunity the parks. However the park's ability to fully exploit these opportunities is doubted due to the constant loss of wild life and habitat largely due overdependence of the population especially, farmers, hunters, and other members jeopardizing the future prospects.

The protectionist believe that strict preservation and protection can total eliminate adverse effect of all forms community activities (Hockings et al., 2006; Geldmann, Joppa \& Burgess, 2014; Cumming et al., 2015; Oruonye et al, 2017) which stem this tide and attain the conservation goal and enhance parks potentials. However, this approach often degenerates into misunderstanding between local communities and managers due to mistrust, skepticism and apathy and its impact is below expectation, increasing the loss of endanger spices and their habitat in the protected areas and national parks (Njogu, 2004). Thus, the effectiveness of this approach is doubted (Ite, 1996; Joppa et al., 2008, McDonald et al., 2008). Because the local communities view the wide life as free gift of nature and main sources of employments, such as farming, hunting, poaching, etc. and there is no justification for protecting them and prohibiting its use at the peril of their livelihood (Tagowa and Buba, 2012).

It also argued that tourism development in national can improve wildlife and habitat and boost potentials of the park. Since tourism development can offer better alternative sources of living through ecotourism, thereby creating for opportunities local communities and improved biodiversity. For tourism development to be effective active participation of local is essential (Jeremy et al 2012; Souto et al. 2014; Garraway, 2017) because local community are the rightful owners of national parks, particularly in SubSaharan Africa where indigenes use the natural resources for agriculture, medicinal, purposes and will not augur well to "tag"them(PA) as restricted areas (Masozera, 2002).

Although, the generally census is that ecotourism provide several opportunities local communities and improved biodiversity, implies that the community support or otherwise in to maximize opportunities of the national and which specific role assign to the community improved biodiversity in national parks and the key focus of community involvement is conservation; to enhance planning and management of the national Parks. This understanding promotes equitable distribution of roles and benefits from the protected areas between the local communities and government (Adams and McShane1992; McNeely et al. 1992; Pimbert and Pretty 1997).

It is also important the local communities should be aware of the environmental, social and economic importance of protected areas (Anteneh et al., 2014). The participation of the local communities in conservation program is due to the perceive feasibility of economic and social benefits from the program (Milner- Gulland et al. 2003), as some recent studies (Obioha et al 2012; Ngoufo et al. 2014) have indicated the invaluable importance and contribution of wildlife products and byeproducts to various livelihood benefits of Oban communities.

Nonetheless considering that tourism development encompass many activities which also broaden the scope of local community involvement to achieve conservation goals There is so far limited explanation about the specific roles of local community involvement as well and tourism development activities which directly influence the 
opportunity of the park since the local community might weight potential costs and benefit before participating.

Higham and Bejder (2008) stressed that benefits accrue to the local communities from biodiversity ensures its sustainability. And through the development of tourism, the conservation of biodiversity can be enhanced, thereby providing enormous economic opportunities to make biodiversity conservation beneficial the local community (World Bank, 2003).

In Nigeria, the issue of local community participation in conservering biodiversity has been given little attention (Adams et al, 2004). The Gashaka Gumti National Park was purposely established to preserves, protect GashakaGumti National park was established for the conservation of biodiversity and support of rural development and traditional livelihood (Tagowa \& Buba, 2012). Even though tourism development was key point part of the goals for creating the National Park (Sommer \& Ross, 2011), yet, the tourism potentials has not been fully exploited as promised.

The situation has created certain doubt and mixed feeling among the indigene, and some are of the view that the establishment of the Park as way to restrict them access to the Park which they consider as legal and traditional rights and which they make use without any restrictions (Adewumi 2016; Adetoro \& Adetola ,2011). Because wildlife and their habitat can boost the opportunities of the park (provision of recreations) which are essential for human well -being, poverty reduction and many more which are much appreciated by local communities. Therefore, the purpose of this article is to identify the factors that influence or predict the outcomes of opportunity of Gashska Gumti National national park.

There is unclear description of local communitiese roles and how their views are incorporated in the whole tourism planning and development process. While the tourism literature suggests a number of roles local communities could take in tourism development, little emphasis has so far been given as to how the local communities themselves feel about these imposed roles. This creates a gap between what communities viewed as their roles in tourism development and as opposed to what the literature suggests.

\section{LITERATURE REVIEW}

\section{$>$ Opportunities of National Parks}

Numerous opportunities exist for the national parks that can exploited for socio-economic if conversation goals are linked the mutual benefits local community. National park rich biodiversity provides enormous economic potentials for recreation and ecotourism and opportunity for employment and generating income (Remme et al., 2015; Demeke and Verma, 2013). Ngoka, 2013 Aruonye et al, 2017).Educating the local community to on need to participation and practiced community base conservation is key to unlock these opportunities. These will reduce some threat of poaching, farming. Effective education and aware of conservation practices. This increase in numbers of wild animals for further exploitation of opportunities increases economic returns through the development of tourism in the area (Demeke and Verma, 2013).

\section{$>$ Influence of Tourism Development Factors on Opportunities of Parks.}

Tourism development aimed at supporting conservation initiative in parks must consider factors that directly enhance the ability of the park to maximize opportunities.

From the outset, the local community support for tourism development is crucial to annexing the opportunities of the park through ecotourism (Sebola \& Fourie 2006; Mensah \& Ernest, 2013). The local people serves as tools for development rather than subjects (Mitchell and Reid, 2001). The local people support tourism development because of the promised benefits. It is believed that the benefits can only be ensured when community is involved and their traditional lifestyles and values respected (Mitchell and Reid 2001,

Sheldon and Abenoja 2001). So local community normally asses feasibility of tourism development potentials based on the promised benefits and costs they will suffer for the decision to support tourism development or otherwise (Amuquandoh (2010). Thus Local Community with positive perceptions tend to support tourism development (Mohammadi, Ramseook-Munhurrun and Naidoo (2011) Ullah and Chowdhury (2013) whereas local community having some doubt decline support to tourism development. Overall, when local residents have more positive perceptions of ecotourism's impacts, they generally demonstrate stronger support for and more active participation in community-based ecotourism (Andereck \& Vogt, 2000).However, in practice, ecotourism often fails to promote the interests of host communities, particularly indigenous communities in marginal and disadvantaged areas (Campbell, 1999; Kontogeorgopoulos, 2005).

Moreover, Tourism development in the park should improve community participation.

Fariborz (2011) asserts that the community must actively participate in all tourism development related activities. It is essential management approach to solicit views of local people before development is initiated $(\mathrm{Li}$ 2006). This will inform tourism planners about the acceptability of the proposed development, views held by community and whether or not any grievance can be addressed by development of appropriate management policy and strategy (Sonmez \& Sirakaya 2002). This will also not only provide happy and healthier residents but will encourage greater participation in civic matters in general, thus, creating more active and concerned citizens (Wilson 2003). Moscardo (2015) pointed out that that exclusion of local community participation in tourism development and planning is a cause of concern. Cattarinnich (2001) argues that community should participate in tourism development 
decision if their livelihoods needs are given priorities and reflected in tourism development agenda.

In addition, tourism development should improve the livelihood of the community. Because local communities view the wide life as free gift of nature and main sources of their survival. Protecting them and prohibiting its use without any sustainable sources of living will jeopardize their livelihood (Tagowa \& Buba, 2012). Mahony and Zyl, (2002) argues that tourism development contribute to economic development, poverty eradication and job creation. The feasibility of livelihood improvement has encouraged several communities to embrace tourism development as an alternative to improve their economic fortunes (Briedenhann \& Wickens, 2004; Busby \& Rendle, 2000; Mair, 2006). Alternatively poor living conditions and lack of financial support discourage community to participate in community based tourism (Sangkyun Kim , Eerang Park, Toulakham Phandanouvong,2014)

Furthermore, the tourism development should bring more job opportunities to local people. As the local communities may be deprived of their main sources opportunities such as farming, hunting, poaching and other sources of employment (Tagowa \& Buba, 2012), local community should be not improved for sacrificing their sources of income. Higham (2008) pointed out that benefits accrue to the local communities from biodiversity ensures its sustainability. And through the development of tourism, the conservation of biodiversity can be enhanced, thereby providing enormous economic opportunities to make biodiversity conservation beneficial the local community (World Bank, 2003).

In addition Aref, 2010; and Coccossis, (2004) assert that tourism offer opportunities for direct, indirect, and induced employment and income Tourism development and community participation Tourism continues to be an agent of economic development, particularly in a setting where there are fewer economic alternatives to tackle poverty and reduce unemployment (Ashley, 2006; Mitchell and Coles, 2009).

Apart from job opportunity the tourism development in the park should benefitted the community financially. Since local people support ecourism development because of promised financially benefits (Mitchell and Reid 2001), Sakala (2018) contended the socio-economic bene (Madaki, et al., 2020) fits derived from wildlife resources have not made a great impact in uplifting the standard of living. Furthermore, households living in GMAs have lower average income than households in other rural areas. However, the study has established that there is a link between sustainable wildlife management and improved rural livelihoods.

Another important factor is tourism development should improve of community participation. As it is generally assumed that local people are willing and able to actively participate equally (Hanafiah et al. 2013). Since this occasion is about decision making process for the mutual benefits of indigenes and ecotourism development (Gibson and Marks 1995; Timothy 1999; Tosun 2000).Improved community participation minimize conflicts and foster understanding of community concerns and enhanced knowledge sharing (Millar and Curtis, 1999; West et al., 2006). Thus ignoring community contributes in tourism development could jeopardize host-tourist relationship which can affect tourist attraction in the location Zhang, Inbakaran, \& Jackson, (2006)

More importantly Tourism development should consider the adversely affect cultural heritage of community. Chen \& Chen, 2012; David \& van der Merwe 2016) assert that heritage tourism is the most thriving niche market and popular form of tourism. Tourism development should maintain and protect the cultural heritage of the local community that boost local economy because of the tourists to sustain due to the shared responsibility that responsibility that tourists feel for these elements (Nuryanti, 1996). Apart from the economic and environmental impacts of tourism, there is also the sociocultural impact that causes positive or negative consequences in terms of social and cultural changes (Gjerald, 2005). Researchers indicate that most developing countries have been influenced by big tourism businesses which impact local values, beliefs, lifestyle and consumption patterns to be more Westernized ( SinclairMaragh \& Gursoy, 2015).

The benefits of actively participating in ecotourism development could be the maintenance of cultural traditions, protection of spiritual sites, and conservation of biodiversity for indigenous people (Nursey-Bray \& Rist, 2009; Smith, Scherrer, \& Dowling, 2009).

Similarly, Tourism development in the parks should not worsen the livelihood of community. There are evidence of that tourism developent has positively enhance the livehillod of the community Goodwin, 2008; Yunis, 2003; Yunis, 2004). As result tourism is now adopted strategy for economic development and allivating poverty (Ijeomah, 2007). Tao \& Wall, (2009) also assert that tourism is more likely to deprived local community livelihood, when government view tourism as means for rapid economy growth can make present forms of livelihood outmoded Mbaiwa (2011) observed changes in livelihood activities and lifestyles may increase local livelihood insecurity. Local livelihoods transform into a "tourism livelihood" Such tourism livelihoods are extremely vulnerable to visitor volatility. As Liu (2003) points out, the tourism industry is highly prone to fluctuations in response to external events (see also Dahles and Prabawa (2013).

Tourism development improve health and sanitation

Following Butler (1993), it is argued that tourism development should not damage the environment in which communities are included and restrict or destroy the livelihood resources and activities available to local people. Among diverse livelihood activities, tourism is only one 
optional strategy which may or may not become a tool of the local people's capacity improvement to secure the sustainability of their livelihood (Tao \& Wall, 2009b). Instead of making tourism sustainable, we argue that local development should take centre stage. For local development to provide sustainable livelihoods, tourism may or may not be a viable strategy and, in some cases, should be avoided.

Tourism development has brought vast infrastructure development to the community

Hovardas and Stamou (2006) indicated that the infrastructure development can further the adverse impact on biodiversity by concentrating local resource use in smaller areas and /or by undermining local resource management systems. In addition to resources depletion habitats destruction, environmental pollution are threats of traditional tourism that have dire consequence on conservation of wildlife and forest and scenic beauty of national parks (Hunter, 2002). The problem of environmental pollution is exacerbated where there is mismanagement of solid waste and littering in remote areas is due to poor drainage system and waste collection Also construction of hotels, recreation, and other facilities often lead to increased sewage pollution which pollutes seas and lakes surrounding tourist attractions thus damaging the flora and fauna. On accounts of these negative effects of tourism development on the corridors of local environment and cultures that ushered in ecotourism in the 1980s and 1990( Richins ,2009). He argues that ecotourism is as an alternative form of tourism founded on the principle and practices that seek to harness tourism's economic potential for biodiversity conservation and sustainable development. It has become an alternative way of paying for nature conservatoion (Uchene, 2010).

Moreover, some ecotourism operations contribute minimally to local development, with little or no ecotourism revenue reaching local people (Jacobson and Robles 1992; Healy 1994; Bookbinder et al. 1998). Even those who profit financially often rely upon an unstable source of income, one subject to seasonal fluctuations, as well as sensitive to economic and political events (Jacobson and Robles 1992; Epler Wood 1998).

\section{MATERIAL AND METHODS}

The study area is Gashaka-Gumti National Park.It is situated at the foot of the Mambilla Plateau and covers a land area of about $6,411 \mathrm{~km} 2$. It lies between latitude $6^{\circ} 55^{\prime} \mathrm{N}$ and $8^{\circ} 05^{\prime} \mathrm{N}$ and longitude $11 \mathrm{o} 13^{\prime}$ to $12^{\circ} 11^{\prime} \mathrm{E}$. The park was originally gazetted as Gumti, Gashaka and Serti Game sanctuaries by the defunct Northeast Government in the 1970's. The three game sanctuaries were merged and upgraded to a National park by the Nigeria National Park Decree of 26th August, 1991 which was repealed by Decree 46 of 1999..Gashaka -Gumti National Park is a vast land of spectacular wilderness $(6,000 \mathrm{~km} 2)$ in the southeast corner of Taraba State, adjoining the Mambilla Plateau (Figs. 1 and 2). The Park is an outstanding tourist landmark in Taraba State and the largest of all the eight national parks in the country (Ayodele 2001). It is a home the most diverse in terms of species such as the colobus monkey and warthogs, including buffalo, roam antelope, chimpanzee, hippopotamus, hyena, giant forest hog, lion and leopard. The park is surrendered by 25 communities; 5 outside, 11 on the periphery and 9 inside, including 6 enclaves (Deshen et al., 2010) belong to different ethnic groups such as Jibu, Dakka,Ndoro, Tigun, Gbaya, Tiv, Mambilla, Kaka and Fulani in the southern part of the park, while in the northern part or Toungo sector are the Chamba, Kutim Potopore, Fulani, Dakka, Nyamnyam and Kona. The main sources occupations are farming, livestock husbandry, vocational jobs, civil service with few hunters and fishermen. The best time to visit the park is during dry season that is between Decembers to March yearly.

\section{$>$ DATA}

The population of this study is the number of households in these communities namely Gashaka Gumti, Selbe, Filinga and Chappal Hendu communities within the Gashaka Gumti National Park. As at 2006 national population Census the total residents of four (4) communities is 15,038(NPC, 2006) number of household 825.The population distribution are as follows: Gashaka Gumti 6762(45\%), Selbe 5284(35\%), Filinga 2472(16.4\%) and Chappal Hendu 520(3.6). In terms number of household, Gashaka Gumti has352(42.7\%), Selbe $301(36.5 \%)$, Filinga 120(14.5\%) and Chappal Hendu $52(6.3 \%)$.In determining the sample size, the study adhered to the advice of Kerlinger (1973) who indicate that "a sample size of $10 \%$ of the target population is large enough so long as it allows for reliable data analysis. Having applied Nassiuma (2000) model, a sample of 87.9 was obtained. However, study used sample size of 200 households for better representation. The stratified random sampling technique in the selection of the sample due to heterogonous nature of the households Bryman (2008), Cooper and Schindler (2011) Saunders et al., (2007) to ensure proportionally allocation of sample.Data were collected through standard questionnaire administered by a team of expert(researcher and wardens of the parks) The questionnaire sought information on demographic data, community participation and tourism development and maximizing opportunity of park based on Gashaka Gumti National Parks. A binary scale was used for tourism development and local community where $1=$ agree $0=$ disagree .For measuring outcomes of opportunity " 1 " is maximizing and " 0 " not maximizing .This questions and scale will be applied to other status of national park ,such as Weakness, strength, opportunities. Out of two hundred questionnaire distributed to the house, 118 were questionnaires fully completed and valid but 8 of them were rejected due to extreme missing data relevant to the data analysis 
ISSN No:-2456-2165

\begin{tabular}{|c|c|}
\hline Dependent Variable & Measurement \\
\hline Outcomes of opportunity of GGNP $\left(\mathrm{Y}_{1}\right)$ & $\begin{array}{c}1=\text { Maximize opportunity of park } \\
0=\text { Not Maximize opportunity of parks }\end{array}$ \\
\hline \multicolumn{2}{|l|}{ Independent Variables } \\
\hline Local community support tourism development $\left(\mathrm{X}_{1)}\right.$ & $1=$ agree $; 0=$ disagree \\
\hline Tourism development support community livelihood $\left(\mathrm{X}_{2}\right)$ & $1=$ agree $; 0=$ disagree \\
\hline Tourism development offers job opportunity to local community $\left(\mathrm{X}_{3}\right)$ & $1=$ agree $; 0=$ disagree \\
\hline Tourism development benefit community financially $\left(\mathrm{X}_{4}\right)$ & $1=$ agree $; 0=$ disagree \\
\hline Tourism development worsen cultural heritage $\left(\mathrm{X}_{5}\right)$ & $1=$ agree $; 0=$ disagree \\
\hline Tourism development Worsen livelihood $\left(\mathrm{X}_{6}\right)$ & $1=$ agree $; 0=$ disagree \\
\hline Tourism development improved community health and sanitation $\left(\mathrm{X}_{7}\right)$ & $1=$ agree $; 0=$ disagree \\
\hline Tourism development improved infrastructure development $\left(\mathrm{X}_{8}\right)$ & $1=$ agree $; 0=$ disagree \\
\hline Community participate in wildlife and forest conversation $\left(\mathrm{X}_{9}\right)$ & $1=$ agree $; 0=$ disagree \\
\hline community take conservation initiative $\left(\mathrm{X}_{10}\right)$ & $1=$ agree $; 0=$ disagree \\
\hline community participate in park patrol and protection $\left(\mathrm{X}_{11}\right)$ & $1=$ agree $; 0=$ disagree \\
\hline community participate in park management policy $\left(\mathrm{X}_{12}\right)$ & $1=$ agree $; 0=$ disagree \\
\hline community promote and local products $\left(\mathrm{X}_{13}\right)$ & $1=$ agree $; 0=$ disagree \\
\hline local government help to local community $\left(\mathrm{X}_{14}\right)$ & $1=$ agree $; 0=$ disagree \\
\hline community participate in tourism development $\left(\mathrm{X}_{15}\right)$ & $1=$ agree $; 0=$ disagree \\
\hline
\end{tabular}

Table 1:- Variables and Measurements

\section{Logistic Regression Analysis}

The aim of the study is to determine tourism development and local participation factors that predict outcomes of opportunity to the Park. Logistic regression is appropriate to predicate categorical dependent variables based independent variables (Hair et al., 2010). Logistic regression model This model has been used by Chok et al (2007) and Mugizi(2017).Using binary logistic regression model allows to analyze the relationship between dichotomous dependent variables and continuous categorical independent variables. That is maximizing or not maximizing opportunity of the Park based on the predictors' factors of local community participation and tourism development. In order to predict category of cases, the odds calculated which probability of maximizing opportunity will occur over the probability of not maximizing opportunity will not occur (According to Kleinbaum, et al., (2008). Thus probability maximizing opportunity will occur is $\mathrm{P}(\mathrm{X})$ and the probability not maximizing opportunity will not occur is $(1-\mathrm{p}(\mathrm{X})$ as shown in equation 1

$$
\text { Odds (Events) } \quad=\frac{\mathrm{p}(\mathrm{x})}{1-\mathrm{P}(\mathrm{x})}
$$

Where, $\pi(\mathrm{x})$ is the probability of success (maximizing opportunity) and $1-\pi(\mathrm{x})$ is the probability of no success (not maximizing opportunity). But, considering that odds ratios show measures the relationship of two events such as maximizing opportunity and not maximizing, An odds ratio of less than one indicates not maximizing opportunity and ratio of above 1 indicate the likelihood of maximizing opportunity .Nevertheless, Since of the outcomes of model is not predict opportunity value (Y) but the probability that maximizing opportunity or not maximizing opportunity which takes value between 0 and 1 a $\log$ transformation was applied resulting
$\operatorname{logit}(y)=\operatorname{Ln}\left[\frac{P(x)}{1-P(x)}\right]$

Where, logit(y) is the natural logarithm of the odds of outcome of event.

Logistic regression model measures the association and strengths among the predictors or independent variables, that is, tourism development and local participation factors to predict opportunity to the Park. Therefore, logistic regression model is, $\operatorname{logit}(\mathrm{y})=\operatorname{Ln}\left[\frac{\mathrm{P}(\mathrm{x})}{1-\mathrm{P}(\mathrm{x})}\right]=\mathrm{a}+\beta 1 \chi 1+\beta 2 \chi 2 \ldots+\beta \mathrm{k} \chi \mathrm{k}$ is estimated with the maximum likelihood methods (ML). But, According to Kutner, et al (2005), the dependent variable in this model takes values 1 and 0 with defined probabilities of success outcome $\pi(\mathrm{x})$ and $1-\pi(\mathrm{x})$ failure outcome respectively. So, Y follows a Bernoulli distribution expressed as $\mathrm{E}(\mathrm{Y})=\pi(\mathrm{xi})$. The relationship between the predictor and response variables is not a linear function in logistic regression instead log it transformation of $\pi$ is used. Consider a collection therefore, $Y=\pi(x i)+e i$

$$
\begin{aligned}
& \mathrm{E}(\mathrm{Y})=\pi(\mathrm{Xi}) \quad=\left[1+\exp \left(-\mathrm{x}^{\mathrm{T}} \beta\right)\right]-{ }^{1} \\
& =\frac{1}{1+\exp \left(-\mathrm{x}^{\mathrm{T}} \beta\right)} \\
& =\mathrm{P}(\mathrm{Y}=1)=\mathrm{P}(\mathrm{SUCCESS})=\pi(\mathrm{Xi}) \\
& =\mathrm{P}(\mathrm{Y}=0)=1-\mathrm{P}(\text { failure })=1-\pi(\mathrm{Xi})
\end{aligned}
$$$$
\frac{\pi}{1-\pi}
$$

Rearranging, resultant outcome of event given by $\mathrm{P}=$

$$
=\frac{\exp (\beta o+\beta 1 \times 1+\beta 2 \times 2 \ldots \ldots p \times p}{1+\exp (\beta o+\beta 1 \times 1+\beta 2 \times 2 \ldots . \beta p X p}
$$


But, the odds $\mathrm{Y}=1$ or success is natural $\log$ transformation of $\mathrm{P}=\left(\frac{\pi}{1-\pi}\right),==\ln \left(\frac{\pi}{1-\pi}\right)=\beta 0+$ $\beta 1 \times 1 \ldots \beta p X p \quad ; \quad$ Where $\beta$ o is constant and

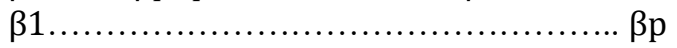

Parameter estimate or regression coefficients of the predictor variables variables.

The estimate parameter in logistic regression is obtained using the maximum likelihood(ML) The maximum likelihood generally, the sample likelihood function is defined as the joint probability function of random variables specifically, suppose $(\mathrm{x} 1, \mathrm{x} 2, \ldots \ldots \ldots, \mathrm{xp})$ are $\mathrm{p}$ independent random observations Since $\mathrm{Yi}$ is the Bernoulli random variable the probability

\section{Logistic Regression methods}

Although several me method exist for selecting variable in the models. There no size fit all, it can be emphasized that there is no one size fit all model that can be applied in all cases and thus there is a need to apply two or more models to the same study for comparison purposes.

The enter stepwise forward and stepwise backward model were used. The enter method include all variables in to model ( factors of local participation and tourism development ) at one step without exception significance .Meanwhile. The forward selection method starts with a null or base model (which includes only the constant, and adds significant variables to the model. On the other hand, backward elimination method starts with the full model (one including all the possible explanatory variables) and removes insignificant variables from the model (Sarkar, Midi, and Rana 2010). These models are widely used when there any predictor variables the variables included in or excluded from the model are determined by likelihood ratio test, score test or Wald test to determine the inclusion or exclusion of variables into the model. It can be emphasized that there is no one size fit all model that can be applied in all cases and thus there is a need to apply two or more models to the same study for comparison purposes. The results of the level of opportunity and strength weakness and opportunity of Ghashaka Gumti National are presented in section. The study used three modeling techniques to predict level of opportunity and level of strengths based on the predicted variables. The three (3)model fitting were the Enter method, forward conditional selection, and backward stepwise conditional elimination method. A comparison of the models to determine the best method of model fitting was also conducted using AIC.

\section{$>$ Model Diagnostics}

After estimating the Logistic regression model parameters using the maximum likelihood estimator, there is a need to assess the significance of the variables with regards to predicting the response variable. There are a number of statistics that can be used to carry out the assessment and these include deviance, likelihood ratio, Wald Test and Score Test (Harrell, 2001).

\section{- The Omnibus Tests of Model Coefficients}

This measure the significance difference logistic regression model with $\mathrm{K}$ predictors variable and model without $\mathrm{K}$ explanatory variables.A chi square test Chisquare test static measures the significance difference between these two models, and since p- value of greater than 0 implying that the current model is significantly better than base or null model.

\section{- Model summary (Testing Goodness -fit- of the model)}

The summary model indicate the goodness of fit of the new model. The chi -square shows the difference between the null model and new model. The -2 Log likelihood value measure the how well the null and current model fit the data. Model with deceased -2 Log likelihood value considered a better Overall, the explanatory power of the model. The Cox \& Snell R2 attempts to explain the amount of variation in the logistic model just like the coefficient of determination in multiple regression model, hence pseudo $\mathrm{R} 2$ value. The static is usually less than 1 which might not explains much of the variations in model.The Nagelkerke R Square which attempt improves on the Cox \& Snell Rsquare to reach a maximum value of one (1)

\section{$>$ Hosmer and Lemeshow Test}

The Hosmer \& Lemeshow test assess the significance difference between the predicted and observed probabilities of the full model to determine the overall goodness of fit of the model. The Homer-Lemeshow test divides the predicted probabilities into 10 groups of subjects and then calculate a Chi-square statistic that compares the predicted to the observed number of groups. A p-value greater 0.05 shows a good fit the data and thus overall model fit.

\section{Classification tables}

A Classification table gauges the predictive accuracy of a multivariate logistic regression model. The method involves cross classifying the dependent variable with the categorical variable emanating from the fitted logistic probabilities (). The percentage of successes that have been correctly classified as success is called sensitivity of the model, whilst the percentage of failures that have been correctly classified is called specificity of the model. The failures that are incorrectly classified as success are referred to as false positive and the success that are incorrectly classified as failures are referred to as false negatives (Sharma, 1996).

\section{RESULTS AND DISCUSSION}

As indicated earlier, the response variable is outcomes of opportunity measured maximizing and not maximizing opportunity of Gashaka Gumti national Park while the independent predictors variables consist of factors of local community participation and tourism development. Table 3 reports summary of descriptive statistics. In terms outcomes of opportunity of the, $53.7 \%$ show the Gashaka National can maximize its opportunity. In view of this, $63.8 \%$ of local community agrees to support tourism development in the park. Because $58 \%$ of the community agrees that Tourism development offers job 
opportunities while $70.2 \%$ of them agree that Tourism development benefit community financially. Nonetheless, the community $(99: 52.7 \%)$ disagree that Tourism development improves community participation. Because of $120(63.8 \%)$ people of community, agree that Tourism development Worsen Cultural heritage. Meanwhile 53.2\% of local community disagree that Tourism development Worsen livelihood. In contrast, $59.6 \%$ disagree that Tourism development improves health and sanitation. After considering the pros and cons of tourism development in the Gashaka Gumti National, 62.2\% of Community is not ready to support wildlife and forest conservation. On the other hand, $75 \%$ and $46.8 \%$ of the Community agree to participate in Park management plans and policies and Community participate in the protection and patrolling of parks respectively. Regarding Community participate in policy making for wide life conservation $48.4 \%$ agree, but $51.6 \%$ disagrees. Finally, the community 125 (65.4\%) opposed the idea of community based conservation.

\begin{tabular}{|c|c|c|c|}
\hline \multirow{4}{*}{ Outcomes of opportunity } & Response & Frequency & Percent \\
\hline & Maximizing & 101 & 53.7 \\
\hline & Not maximizing & 87 & 45.6 \\
\hline & Total & 188 & 100 \\
\hline \multirow{3}{*}{$\begin{array}{l}\text { Community support tourism } \\
\text { development in the park }\end{array}$} & disagree & 68 & 36.2 \\
\hline & agree & 120 & 63.8 \\
\hline & Total & 188 & 100 \\
\hline \multirow{3}{*}{$\begin{array}{l}\text { Tourism development offer } \\
\text { job opportunities to local } \\
\text { people }\end{array}$} & disagree & 79 & 42.0 \\
\hline & agree & 109 & 58.0 \\
\hline & Total & 188 & 100 \\
\hline \multirow{3}{*}{$\begin{array}{l}\text { Tourism development benefit } \\
\text { community financially }\end{array}$} & disagree & 56 & 29.8 \\
\hline & agree & 132 & 70.2 \\
\hline & Total & 188 & 100 \\
\hline \multirow{3}{*}{$\begin{array}{l}\text { Tourism development } \\
\text { improve community } \\
\text { participation }\end{array}$} & disagree & 99 & 52.7 \\
\hline & agree & 89 & 47.3 \\
\hline & total & 188 & 100 \\
\hline \multirow{3}{*}{$\begin{array}{c}\text { Tourism Worsen Cultural } \\
\text { heritage }\end{array}$} & disagree & 68 & 36.2 \\
\hline & agree & 120 & 63.8 \\
\hline & total & 188 & 100 \\
\hline \multirow{3}{*}{$\begin{array}{l}\text { Tourism development Worsen } \\
\text { livelihood of Community }\end{array}$} & disagree & 100 & 53.2 \\
\hline & agree & 88 & 46.8 \\
\hline & total & 188 & 100 \\
\hline \multirow{3}{*}{$\begin{array}{l}\text { Tourism development } \\
\text { improves health and } \\
\text { sanitation }\end{array}$} & disagree & 112 & 59.6 \\
\hline & agree & 76 & 40.4 \\
\hline & total & 188 & 100 \\
\hline \multirow{3}{*}{$\begin{array}{l}\text { Community support wildlife } \\
\text { and forest conservation }\end{array}$} & disagree & 117 & 62.2 \\
\hline & agree & 71 & 37.8 \\
\hline & total & 118 & 100 \\
\hline \multirow{3}{*}{$\begin{array}{l}\text { Community participate in } \\
\text { Park management plans and } \\
\text { policies }\end{array}$} & disagree & 47 & 25.0 \\
\hline & agree & 141 & 75.0 \\
\hline & total & 188 & 100 \\
\hline \multirow{3}{*}{$\begin{array}{l}\text { Community participate in the } \\
\text { protection and patrolling of } \\
\text { parks }\end{array}$} & disagree & 100 & 53.2 \\
\hline & agree & 88 & 46.8 \\
\hline & total & 188 & 100 \\
\hline \multirow{3}{*}{$\begin{array}{c}\text { Community participate in } \\
\text { policy making for wide life } \\
\text { conservation }\end{array}$} & disagree & 97 & 51.6 \\
\hline & agree & 91 & 48.4 \\
\hline & total & 188 & 100 \\
\hline \multirow{3}{*}{$\begin{array}{l}\text { Support community based } \\
\text { conservation }\end{array}$} & disagree & 123 & 65.4 \\
\hline & agree & 65 & 34.6 \\
\hline & total & 188 & 100 \\
\hline
\end{tabular}

Table 2:- Results of Descriptive Statistics 
Table 3 presents summary results of Omnibus Tests of Model. These results were obtained from Enter method, Forward Stepwise method and Backward Stepwise Methods. The enter model showed ( chi square $=27.752, \mathrm{df}=16, \mathrm{p}<.034$ ). The Forward Stepwise method also reported (chi square $=18.723$, df $=1, \mathrm{p}<.000)$ while Backward Stepwise Methods results were $\left(\mathrm{X}^{2}=26.690\right.$, $\mathrm{df}=4$, $\mathrm{p}$-value $=0.00$ ). These results imply that the current model is significantly better than the null model. Therefore, the null hypothesis is rejected because $\mathrm{p}$ - values for the new model were greater than 0 . This means that additional variable improves the model to predict outcomes of opportunity of the Gashaka Gumti Park.

\begin{tabular}{|c|c|c|c|c|}
\hline \multicolumn{2}{|c|}{ Enter Method } & Chi-square & Df & Sig. \\
\hline \multirow{3}{*}{ Step 1} & Step & 27.752 & 16 & .034 \\
\hline & Block & 27.752 & 16 & .034 \\
\hline & Model & 27.752 & 16 & .034 \\
\hline \multicolumn{2}{|c|}{ Forward Stepwise method } & Chi-square & $\mathrm{df}$ & Sig. \\
\hline \multirow{3}{*}{ Step 1} & Step & 18.723 & 1 & .000 \\
\hline & Block & 18.723 & 1 & .000 \\
\hline & Model & 18.723 & 1 & .000 \\
\hline \multicolumn{2}{|c|}{ Backward Stepwise Methods } & Chi-square & Df & Sig. \\
\hline \multirow{3}{*}{ Step $13^{\mathrm{a}}$} & Step & -2.363 & 1 & .124 \\
\hline & Block & 26.690 & 4 & .000 \\
\hline & Model & 26.690 & 4 & .000 \\
\hline
\end{tabular}

a. A negative Chi-squares value indicates that the Chi-squares value has decreased from the previous step.

\section{Table 3:- Omnibus Tests of Model Coefficients}

Regarding the goodness of fit of the new model, the summary model results are shown in Table 4.1.The enter method shows -2 Log likelihood value (231.828) for the full model and that of the null hypothesis or base model (259.58). Based on the results, the new model is far better than constant model because additional explanatory variable decreased the -2 Log likelihood value by (259.58$231.828=27.752$ ) which equal to the chi square static in Omnibus Test of model. Similarly Forward stepwise method reported -2 Log likelihood value for the full model is (225.413) as compared to null model (253.687) implying that a decreased in the -2 Log likelihood values (253.687$234.964=18.723$ ) improved the predictive power of the model. Table 4.33 indicates how the model fit the data. The -2 Log Likelihood result for the full model(226.997) and the base model (null model ) was (253.687), indicating a decrease of $26.690=(253.687-226.997)$ which improved the full model after addition variable than the base model the considered only constant coefficient. This means all three methods improve the explanatory power of the model has been significantly improved and which implies that either can predict the outcome of opportunity of the Ghaka Park.

In terms of explanatory power of the model, Enter methods reported Cox \& Snell R2 $13.7 \%$ as explained variations while Nagelkerke R Square which attempt improves on the Cox \& Snell R-square reach a maximum value of one (1) was $12.8 \%$. The Forward Stepwise method, showed The Cox \& Snell R2 explained only of 9.5\% variations in level Nagelkerke $\mathrm{R}$ improved the valued to $12.8 \%$. Similarly, backwards methods reported The Cox \& Snell R2 13.2\% and Nagelkerke R Square was $17.9 \%$. These results imply that independent variables did not explain much of the variations in the maximizing or not maximizing opportunity of Gashaka Gumti National.

These values were insignificant indicating that much of the variations in the model were unexplained. With Backwards methods, The Cox \& Snell R2 was only of $13.2 \%$ and Nagelkerke R Square was $17.9 \%$ These results imply that independent variables did not explain much of the variations in the level of opportunity to Gashaka Gumti National. These values were insignificant implying that much of the variations in the model were unexplained. Based on the Forward Stepwise method, The Cox \& Snell R2 explained only of $9.5 \%$ variations in level of opportunity or model while Nagelkerke R improved the valued to $12.8 \%$. These values were insignificant indicating that much of the variations in the model were unexplained. With Backwards methods, The Cox \& Snell R2 was only of $13.2 \%$ and Nagelkerke R Square was $17.9 \%$ These results imply that independent variables did not explain much of the variations in the level of opportunity to Gashaka Gumti National. 
ISSN No:-2456-2165

\begin{tabular}{|c|c|c|c|}
\hline \multirow{2}{*}{$\begin{array}{l}\text { Enter Method } \\
\quad \text { Step 1 }\end{array}$} & -2 Log likelihood & Cox \& Snell R Square & Nagelkerke R Square \\
\hline & $231.828^{\mathrm{a}}$ & .137 & .183 \\
\hline \multicolumn{4}{|c|}{ a. Estimation terminated at iteration number 4 because parameter estimates changed by less than .001 . } \\
\hline \multirow{2}{*}{$\begin{array}{l}\text { Forward Stepwise method } \\
\text { Step } 2\end{array}$} & -2 Log likelihood & Cox \& Snell R Square & Nagelkerke R Square \\
\hline & $225.413^{\mathrm{a}}$ & .140 & .189 \\
\hline \multicolumn{4}{|c|}{ a. Estimation terminated at iteration number 4 because parameter estimates changed by less than .001 . } \\
\hline \multirow{2}{*}{$\begin{array}{c}\text { Backward Stepwise Method } \\
\text { Step } 13\end{array}$} & -2 Log likelihood & Cox \& Snell R Square & Nagelkerke R Square \\
\hline & $226.997^{\mathrm{a}}$ & .132 & .179 \\
\hline
\end{tabular}

Table 4:- Model Summary

Hosmer and Lemeshow Test

Table 5 presents summary of The Hosmer \& Lemeshow test results which assessed the significance similarity between the predicted and observed probabilities of the full model. Enter method reported $\mathrm{X}^{2}(8)$ of 6.744 and $\mathrm{p}$-value 0.565 , implying null model is fit and overall significantly fit the data. Similarly, the Forward Stepwise method reported $\left(X^{2} \cdot 420, \mathrm{df}=8\right.$ and $\left.\mathrm{P}>0.05\right)$ indicating that new model is not good fit to the data. Likewise, Backward stepwise method reported $\mathrm{X}^{2}(8)$ of 3.646 and $\mathrm{p}$-value 0.820 which indicating a poor goodness of fit of the full model which not acceptable.

\begin{tabular}{|c|c|c|c|}
\hline Model & Chi-square & df & Sig. \\
\hline Enter method Step 1 & 6.744 & 8 & .565 \\
\hline Forward Stepwise method Step 2 & .420 & 8 & .810 \\
\hline Backward Stepwise Method Step 13 & 3.646 & 7 & .820 \\
\hline
\end{tabular}

Table 5:- Hosmer and Lemeshor

\section{> Interpretation of the Model}

Results of variables in the model are shown in Table.5. The enter method, based on the Wald test found only community initiative was significant in the estimation of the odds of maximizing opportunity of Gashaka Gumti National Park because the p-value of 0.049 is less than 0.05. This result means that the local communities in Gashaka Gumti national would like to participate in conservative initiative. This finding is consistent with the study ( Isiugo \& Obioha 2015) but contradict the results of Eshun, 2008. Moreover, forward Stepwise method found community support for tourism development is community participation in park management policy were significant with. The coefficient for community support for tourism development was 0.766 . This means that $\exp (\beta)=0.766$ $\approx 2.151$. Therefore, a unit increase in community support for tourism development leads to increase of (2.151-1) x 100\% $=115.1 \%$ in the odds of maximizing opportunity of the park. Thus, community support for tourism development and maximizing opportunities of the park are positively related. This means that increase in community support for tourism development leads to maximizing opportunity. Moreover, the parameter estimate for community participation in park management policy was 0.678 . This implies that $\exp (\beta)=0.67 \approx 1.970$. Therefore, a unit increase in community participation in park management leads to increase of $(1.970-1) \times 100 \%=97 \%$ in the odds of maximizing opportunity of the park indicating positive relation .Thus, local communities are more likely to take part in park management policy formulation process.
Meanwhile Backward Stepwise method reported coefficient community support for tourism development was -0.687 . This means that $\exp (\beta)=-0.687 \approx 0.502$. Therefore, a unit decrease in community support for tourism development leads to decrease of (0.502-1) $\mathrm{x}$ $100 \%=-49.8 \%$ in the odds of maximizing opportunity of the park. Hence, local community is less likely to support tourism development. Moreover, the parameter estimate for tourism helps local communities to participate in biodiversity was 0.700 . This implies that $\exp (\beta)=0.700 \approx 2.014$. Therefore, a unit increase in help local community management leads to increase of $(2.014$ -1) $\mathrm{x} 100 \%=101.4 \%$ in the odds of the maximizing opportunity of the park, indicating that community are willing support tourism initiates. Meanwhile, the coefficient for tourism development brings job opportunity was -0.881 and $\exp (\beta)=-0.881 \approx 0.441$. Thus, a unit increase tourism development brings job opportunity would lead to a decrease of $(0.441-1) \times 100 \%=55.9 \%$ in the odds of maximizing opportunity of the park. This indicates local communities are less likely to involve in tourism development if the job opportunity decreases .Similarly, the coefficient for community initiative to conserve biodiversity was 0.653 which also indicate $\exp (\beta)=-0.653 \approx 1.920$. This shows that unit change in community initiative to conserve biodiversity in Gashaka Gumti national park would result in increases of $(1.920-1) \times 100 \%=92.0 \%$ in the odds of maximising opportunity of the park. In that case, as the local communities would be more likely to take conservative initiative impacting positively conservation activies in the park. 
ISSN No:-2456-2165

\begin{tabular}{|c|c|c|c|c|c|c|c|}
\hline & Enter Method & $\mathrm{B}$ & S.E. & Wald & $\mathrm{df}$ & Sig. & $\operatorname{Exp}(\mathrm{B})$ \\
\hline Step & Sup_Tourism_Deve & .653 & .415 & 2.480 & 1 & .115 & 1.921 \\
\hline 1 & Help to local Community & -.707 & .380 & 3.454 & 1 & .063 & .493 \\
\hline & Community_livelihood & .002 & .383 & .000 & 1 & .996 & 1.002 \\
\hline & Job Opportunity & .772 & .425 & 3.307 & 1 & .069 & 2.164 \\
\hline & Financial Benefits & .027 & .393 & .005 & 1 & .945 & 1.028 \\
\hline & Community_Participation & .371 & .391 & .899 & 1 & .343 & 1.449 \\
\hline & worsen_culturalherittage & .469 & .357 & 1.723 & 1 & .189 & 1.598 \\
\hline & Worsen_livelihood & -.091 & .348 & .069 & 1 & .793 & .913 \\
\hline & Improved_health sanitation & -.019 & .339 & .003 & 1 & .954 & .981 \\
\hline & Infrastructure development & -.035 & .331 & .011 & 1 & .917 & .966 \\
\hline & Wildlife_forest_Conservation & .373 & .413 & .815 & 1 & .367 & 1.452 \\
\hline & Community_intiative & -.671 & .340 & 3.883 & 1 & .049 & .511 \\
\hline & Park_management_Policy & .416 & .344 & 1.461 & 1 & .227 & 1.516 \\
\hline & Park_Protection_Patrol & .332 & .344 & .931 & 1 & .335 & 1.393 \\
\hline & Promotion_local_products & .051 & .335 & .023 & 1 & .880 & 1.052 \\
\hline & Constant & -1.490 & .624 & 5.705 & 1 & .017 & .225 \\
\hline
\end{tabular}

a. Variable(s) entered on step 1: Sup_Tourism_Deve, Help_to_local_Comm, Community livelihood, Job Opportunity, Financial Benefits, Community Participation, worsen cultural heritage, Worsen_livelihood, Improved_healthsantitaion, Infrastructure development, Wildlife_forest_Conservation, Community_intiative, Park_management_Policy, Park_Protection_Patrol, Promotion_local_products,

\begin{tabular}{|l|c|c|c|c|l|l|l|}
\hline \hline \multicolumn{2}{|c|}{ Step Forward Method } & B & S.E. & Wald & df & Sig. & Exp(B) \\
\hline \multirow{3}{*}{ Step 2 } & & & & & & & \\
& Sup_Tourism_Deve(1) & 1.049 & .350 & 8.980 & 1 & .003 & 2.853 \\
\cline { 2 - 8 } & Park_management_Policy & 1.308 & .322 & 16.494 & 1 & .000 & 3.700 \\
\cline { 2 - 8 } & Constant & -1.740 & .344 & 25.545 & 1 & .000 & .176 \\
\hline
\end{tabular}

a. Variable(s) entered on step 1: Park_management_Policy.

b. Variable(s) entered on step 2: Sup_Tourism_Deve.

\begin{tabular}{|c|c|c|c|c|c|c|c|}
\hline \multicolumn{2}{|c|}{ Backward Stepwise Method) } & B & S.E. & Wald & Df & Sig. & Exp(B) \\
\hline \multirow{3}{*}{$\begin{array}{c}\text { Step } \\
13^{\text {a }}\end{array}$} & Sup_Tourism_Deve & 689 & .347 & 3.949 & 1 & .047 & .502 \\
\cline { 2 - 8 } & Help_to_local_Comm & .700 & .354 & 3.912 & 1 & .048 & 2.014 \\
\cline { 2 - 8 } & Job Opportunity & .881 & .386 & 5.207 & 1 & .023 & .414 \\
\cline { 2 - 8 } & worsen cultural heritage & -.573 & .329 & 3.041 & 1 & .081 & .564 \\
\cline { 2 - 8 } & Community_intiative & .653 & .329 & 3.934 & 1 & .047 & 1.920 \\
\cline { 2 - 8 } & Park_management_Policy & -.546 & .321 & 2.902 & 1 & .088 & .579 \\
\cline { 2 - 8 } & Constant & .347 & .337 & 1.061 & 1 & .303 & 1.415 \\
\hline
\end{tabular}

a. Variable(s) entered on step 1: Sup_Tourism_Deve, Help_to_local_Comm, Community livelihood, job Opportunity, Financial

Benefits, Community_Participation, worsen_culturalherittage, Worsen livelihood, Improved_healthsantitaion, Infrastructure development, Wildlife_forest_Conservation, Community_intiative, Park_management_Policy, Park_Protection_Patrol, Promotion_local_products, Policymaking, Support_Community_based_cons.

Table 6:- Variables in the Equation

\section{Classification Table}

The classification table shows how well the full model predicts cases to the two of the dependent variables not maximizing and maxmising opportunity shown in Table 7. The classification was conducted for both specificity, which is the proportion of the correctly classified "not maximise opportunity at $58.3 \%$ and the sensitivity which is the proportion of the correctly classified maximise opportunity was $68.6 \%$. The overall full model correct classification was $63.9 \%$. The classification table shows how well the full model predicts cases to the two of the dependent variable, level of opportunity shown in Table 7. The classification table was conducted for both specificity, which is the proportion of the correctly classified "not 
maximizing" available opportunity of the park at $41.4 \% .3$ $\%$ and the sensitivity which is the proportion of the correctly classified "high" in level of opportunity was $76.2 \%$. The overall full model correct classification was $60.1 \% \%$. The classification table shows how well the full model predicts cases to the two of the dependent variables shown in The classification table was conducted for both specificity, which is the proportion of the correctly classified not maximizing opportunity at $54.3 \%$ and the sensitivity which is the proportion of the correctly classified "maximizing opportunity was $71.3 \%$. The overall full model correct classification was $63.3 \%$.

\begin{tabular}{|c|c|c|c|c|c|}
\hline \multirow{2}{*}{\multicolumn{3}{|c|}{ Observed }} & \multicolumn{3}{|c|}{ Predicated } \\
\hline & & & \multicolumn{2}{|c|}{ Outcomes Of Maximizing Opportunity } & \multirow{2}{*}{$\begin{array}{c}\text { Percentage } \\
\text { Correct }\end{array}$} \\
\hline Step $1^{\mathrm{a}}$ & \multirow{3}{*}{$\begin{array}{l}\text { Outcomes of } \\
\text { Maximizing } \\
\text { Opportunity }\end{array}$} & & Not Maximizing & Maximizing & \\
\hline \multirow{3}{*}{ Enter Method } & & Not maximize & 51 & 38 & 58.3 \\
\hline & & Maximize & 32 & 69 & 68.6 \\
\hline & Overall Percentage & & & & 63.9 \\
\hline Step $2^{\mathrm{a}}$ & \multirow{3}{*}{$\begin{array}{l}\text { Outcomes of } \\
\text { Maximizing } \\
\text { Opportunity }\end{array}$} & & Not Maximizing & Maximizing & \\
\hline \multirow{3}{*}{$\begin{array}{c}\text { Forward Stepwise } \\
\text { Method }\end{array}$} & & Not maximize & 36 & 51 & 41.4 \\
\hline & & Maximize & 24 & 77 & 76.2 \\
\hline & Overall Percentage & & & & 60.1 \\
\hline Step $12^{\mathrm{a}}$ & \multirow{3}{*}{$\begin{array}{l}\text { Outcomes of } \\
\text { Maximizing } \\
\text { Opportunity }\end{array}$} & & Not Maximizing & Maximizing & \\
\hline \multirow{3}{*}{$\begin{array}{c}\text { Backward } \\
\text { Stepwise Method }\end{array}$} & & Not maximize & 47 & 40 & 54.0 \\
\hline & & Maximize & 29 & 72 & 71.3 \\
\hline & Overall Percentage & & & & 63.3 \\
\hline
\end{tabular}

a. The cut value is .500

Table 7:- Classification Table

\section{Validation of New model}

Based on the classification accuracy of the fitted new model of outcomes opportunity maximisation, it was observed that correct classification of was $1.5(63.9 \%$ $62.2 \%$ )less than the new fitted model of overall outcomes of maximizing opportunity Therefore, it can conclude that the new model replicated. Based on the classification accuracy of the fitted new model it was observed that correct classification, it was observed that the classification accuracy was 6.4 less than the new fitted model $(60.1 \%$ and $53.7 \%$ respectively). Therefore, it can conclude that the new model replicated. .Based on the classification accuracy of the fitted new model it was observed that correct classification, it was observed that the classification accuracy was 0.8 less than the new fitted model $(63.3 \%$ and
$62.2 \%$ respectively). Therefore, it can conclude that the new model replicated.

Selection of Binary Logistic Methods of model Fitting outcomes of opportunity

Table 8 shows the comparison of binary logistic methods of model fitting. The Akaike's Information Criterion (AIC) was used which take into accounts the loglikelihood static and significant independent variables in the model. Based on AIC values (Enter method=233.828, forwards stepwise method $=238.964$ and backwards methods $=232.997)$. Thus it can be concluded that backward stepwise selection method offered the best model fitting as shown in Table 8.

\begin{tabular}{|c|c|c|c|c|}
\hline \multirow{4}{*}{ Model summary } & Indicators & Enter Model & Forward selection model & $\begin{array}{c}\text { Backward selection } \\
\text { model }\end{array}$ \\
\hline & -2Log likelihood & 231.828 & 234.964 & 226.997 \\
\hline & Cox \& Snell R Square & $13.7 \%$ & $9.5 \%$ & $13.2 \%$ \\
\hline & Nagelkerke R Square & $18.3 \%$ & $12.8 \%$ & $17.9 \%$ \\
\hline Classification & Model Fitting accuracy & $63.9 \%$ & $60.1 \%$ & $63.3 \%$ \\
\hline \multirow[t]{4}{*}{$\begin{array}{c}\text { Significant } \\
\text { independent variables }\end{array}$} & & $\begin{array}{c}\text { Community } \\
\text { conservative initiative }\end{array}$ & $\begin{array}{c}\text { Support tourism } \\
\text { development }\end{array}$ & $\begin{array}{l}\text { Support tourism } \\
\text { development }\end{array}$ \\
\hline & & & $\begin{array}{c}\text { Community participate } \\
\text { in park management } \\
\text { policy }\end{array}$ & $\begin{array}{l}\text { Help to local } \\
\text { community }\end{array}$ \\
\hline & & & & $\begin{array}{l}\text { Tourism development } \\
\text { bring job opportunity }\end{array}$ \\
\hline & & & & $\begin{array}{c}\text { Community } \\
\text { conservation initiative }\end{array}$ \\
\hline AIC & & 233.828 & 238.964 & 232.997 \\
\hline
\end{tabular}

Table 8:- Binary logistic Model fitting comparison 


\section{DISCUSSION}

The backward selection method of binary logistic regression produced the best model fitting for predicating outcomes of maximizing opportunity of the Gashka Gumti National Parks Community support for tourism development activities essential to biodiversity conservation in Gashaka Gumti national which can help the park to maximize opportunities. As the community perceives the feasibility of job opportunity, they would be motivated to participate in tourism development thereby maximizing opportunity of the park and improved the livelihood of local community as well. By virtue local; community would be more willing to participate by taken local community initiative to conserve biodiversity which would significantly impact maximizing opportunity in attempt to conserves wild life .In doing this, local community must be helped to sustain conservation initiative to maximizing opportunity of the park .

\section{CONCLUSION}

The aim of paper was to examine influence of tourism development and local community participation factors opportunity of park. I can be conclude that local community for tourism development, Help to local community Tourism development bring job opportunity and local community takes conservative initiative were the factors influeing the odds of maximizing the opportunity of Gashaka Gumti national park. These results confirm and contradict with previous studies in mostly on biodiversity conservation, but predication outcomes of opportunity, where little in known. This paper has shown that not all tourism development activities would be relevant to local community in attempt to maximize the potentially of national and conserve wildlife and habitat, particularly in Gashaka Gumti National Park, Nigeria. Generally, the findings of the study indicate a significant positive relationship in the odds of maximizing opportunity of the Gashaka which significantly contribute to empirical studies and fill and extend gaps in existing literature.

By implication, managers of the park based on the impact of community support for tourism development on maximizing opportunity of the park could help achieve successful conservation goals and thus strategically position park as attractive tourist destination for both local and international to boost its tourism potentials. In addition, tourism development brings job opportunity and positive impact of biodiversity it make possible for integrative natural resources management in protect areas considering the fact that local people claim as gift to be legitimate owners .Effective management with locals help identify feasible alternative sources of incomes to enhance community welfare would further increased and sustained local community support to curtail activities threatening wildlife thereby maximizing opportunity of the park. Local Community conservation initiative facilitates allow managers broadened stakeholder participation to achieve overall conservation goal and local community livelihood.

\section{$>$ Limitations of the Study}

Although the findings are consistent with previous studies but its applicability is limited to the case of management of Gashaka Gumti National Park relating local communities' participation and tourism development in the park. This make necessary to for in-depth appraisal and evaluation before implantation to negatively impact biodiversity and maximizing. This means the local community has become a useful sorting devise for tourism development at Gashaka Gumti national park and crucial in development of tourism programs.

\section{REFERENCES}

[1]. Adams, J. S., \& McShane, T. O. (1992). The myth of wild Africa: conservation without illusion. Berkeley.

[2]. Adetoro, A. O., Lawal, M. S., \& Jenyo-Oni, A. (2011). Biodiversity conservation and community participation in Kainji Lake National Park, Nigeria. Advances in Applied Science Research, 2(2), 218-226.

[3]. Omotesho, O. A., Adewumi, M. O., MuhammadLawal, A., \& Ayinde, O. E. (2016). Determinants of food security among the rural farming households in Kwara State, Nigeria. African Journal of General Agriculture, 2(1).

[4]. Amuquandoh, F. E. (2010). Residents' perceptions of the environmental impacts of tourism in the Lake Bosomtwe Basin, Ghana. Journal of sustainable tourism, 18(2), 223-238.

[5]. Andereck, K. L., \& Vogt, C. A. (2000). The relationship between residents' attitudes toward tourism and tourism development options. Journal of Travel research, 39(1), 27-36.

[6]. Belayneh, A., \& Bussa, N. F. (2014). Ethnomedicinal plants used to treat human ailments in the prehistoric place of Harla and Dengego valleys, eastern Ethiopia. Journal of Ethnobiology and Ethnomedicine, 10(1), 1-17.

[7]. Aref, F. (2010). Residents' Attitudes towards Tourism Impacts: A Case Study of Shiraz, Iran. Tourism Analysis, 15(2), 253-261.

[8]. Coccossis, H. (2008). Cultural heritage, local resources and sustainable tourism. International journal of services technology and management, 10(1), 8-14.

[9]. Coccossis, H. (2004). Sustainable tourism and carrying capacity: a new context. In The challenge of tourism carrying capacity assessment: Theory and practice (pp. 3-14). Ashgate.

[10]. Schroeder, M. A., Ashley, P., \& Vander Haegen, M. (2006). Terrestrial wildlife and habitat assessment on Bonneville Power Administration-funded wildlife areas in Washington: monitoring and evaluation activities. Washington Department of Fish and Wildlife.

[11]. Mitchell, J., Keane, J., \& Coles, C. (2009). Trading up: How a value chain approach can benefit the rural 
poor. London: $\quad$ COPLA Global: Overseas Development Institute.

[12]. Mitchell, J., \& Coles, C. (2009). Enhancing private sector and community engagement in tourism services in Ethiopia. Project Report for the World Bank.

[13]. Ashley, C., \& Mitchell, J. (2009). Tourism and poverty reduction: Pathways to prosperity. Taylor \& Francis.

[14]. Ayodele, J. T., \& Ahmed, A. (2001). Monitoring air pollution in Kano municipality by chemical analysis of Scots Pine (Pinus sylvestris L.) needles for sulphur content. Environmentalist, 21(2), 145-151.

[15]. Ayodele, J. T., \& Abubakkar, M. B. (2001). Trace metal levels in Tiga Lake, Kano, Nigeria. Tropical Environmental Resources, 3, 230-237.

[16]. Bookbinder, M. P., Dinerstein, E., Rijal, A., Cauley, H., \& Rajouria, A. (1998). Ecotourism's support of biodiversity conservation. Conservation Biology, 12(6), 1399-1404.

[17]. Briedenhann, J., \& Wickens, E. (2004). Tourism routes as a tool for the economic development of rural areas-vibrant hope or impossible dream?. Tourism management, 25(1), 71-79.

[18]. Bryman, A. (2008). Social Research Methods. ed. sl: Oxford University Press.

[19]. Busby, G., \& Rendle, S. (2000). The transition from tourism on farms to farm tourism. Tourism management, 21(6), 635-642.

[20]. Mair, J., \& Marti, I. (2006). Social entrepreneurship research: A source of explanation, prediction, and delight. Journal of world business, 41(1), 36-44.

[21]. Butler, R. W. (1999). Sustainable tourism: A state-ofthe-art review. Tourism geographies, 1(1), 7-25.

[22]. Campbell, L. M. (1999). Ecotourism in rural developing communities. Annals of tourism research, 26(3), 534-553.

[23]. THETSANE, M. (2019). Local community participation in tourism development: The case of Katse villages in Lesotho. Athens Journal of Tourism, 6(2), 123-140.

[24]. Cattarinnich X (2001) PPT Working Paper No.8 Pro-Poor Tourism Initiatives in Developing Countries: Analysis of Secondary Case Studies. University of Alberta, Canada, 97. Retrieved from http//wwwPropoortourism.org.uk/initiatives cs. PDF. [Accessed 3 July 2020].

[25]. Cattarinich, X. (2001). Pro-poor tourism initiatives in developing countries: Analysis of secondary case studies.

[26]. Chen, C. F., \& Chen, P. C. (2012). Exploring Tourists' Stated Preferences for Heritage Tourism Services-the Case of Tainan City, Taiwan. Tourism Economics, 18(2), 457-464.

[27]. Chok, S., Macbeth, J., \& Warren, C. (2007). Tourism as a tool for poverty alleviation: A critical analysis of 'pro-poor tourism'and implications for sustainability. Current issues in Tourism, 10(2-3), 144-165.

[28]. Kennedy, H. P., Farrell, T., Paden, R., Hill, S., Jolivet, R. R., Cooper, B. A., \& Schindler Rising, S. (2011). A randomized clinical trial of group prenatal care in two military settings. Military medicine, 176(10), 1169 1177.

[29]. Abrams, A. (2015). Problematizing Protected Areas by Introducing Edge-Dwellers. EnviroSociety Blog, 18 .

[30]. Dahles, H., \& Prabawa, T. S. (2013). Entrepreneurship in the informal sector. The case of the Pedicab Drivers of Yogyakarta, Indonesia. Journal of Small Business \& Entrepreneurship, 26(3), 241259.

[31]. Van der Merwe, C. D. (2016). Tourist guides' perceptions of cultural heritage tourism in South Africa.Bulletin of Geography. Socio-economic Series, 34(34), 117-130.

[32]. Asmamaw, D., \& Verma, A. (2013). Ecotourism for environmental conservation and community livelihoods, the case of the Bale Mountain National Park, Ethiopia. Journal of Environmental Science and Water Resources, 2(8), 250-259.

[33]. Epler Wood, M. (1998). Meeting the global challenge of community participation in ecotourism: Case studies and lessons from Ecuador. Arlington, VA: The Nature Conservancy.

[34]. Walker, R. M., Damanpour, F., \& Devece, C. A. (2011). Management innovation and organizational performance: The mediating effect of performance management. Journal of Public Administration Research and Theory, 21(2), 367-386.

[35]. Gibson, C. C., \& Marks, S. A. (1995). Transforming rural hunters into conservationists: an assessment of community-based wildlife management programs in Africa. World development, 23(6), 941-957.

[36]. Goodwin, H. (2008). Tourism, local economic development, and poverty reduction. Applied Research in Economic Development, 5(3), 55-64.

[37]. Gjerald, O. (2005). Sociocultural impacts of tourism: A case study from Norway. Journal of Tourism and Cultural Change, 3(1), 36-58.

[38]. Hair, J. F., Sarstedt, M., Ringle, C. M., \& Mena, J. A. (2012). An assessment of the use of partial least squares structural equation modeling in marketing research. Journal of the academy of marketing science, 40(3), 414-433

[39]. . Hanafiah, M. H., Jamaluddin, M. R., \& Zulkifly, M. I. (2013). Local community attitude and support towards tourism development in Tioman Island, Malaysia. Procedia-Social and Behavioral Sciences, 105, 792-800.

[40]. Healy, R. G. (1994). The "common pool" problem in tourism landscapes. Annals of Tourism Research, 21(3), 596-611.

[41]. Healy, R. G. (1994). Tourist merchandise'as a means of generating local benefits from ecotourism. Journal of sustainable tourism, 2(3), 137-151.

[42]. Remme, R. P., Edens, B., Schröter, M., \& Hein, L. (2015). Monetary accounting of ecosystem services: A test case for Limburg province, the Netherlands. Ecological Economics, 112, 116-128.

[43]. Higham, J. E., Bejder, L., \& Lusseau, D. (2008). An integrated and adaptive management model to address 
the long-term sustainability of tourist interactions with cetaceans. Environmental conservation, 294-302.

[44]. Higham, J. E., \& Bejder, L. (2008). Managing wildlife-based tourism: edging slowly towards sustainability?. Current issues in tourism, 11(1), 7583.

[45]. Hovardas, T., \& Stamou, G. P. (2006). Structural and narrative reconstruction of rural residents' representations of 'nature', 'wildlife', and 'landscape'. Biodiversity \& Conservation, 15(5), 1745 .

[46]. Hunter, J. T., \& Sheringham, P. (2008). Vegetation and floristic diversity in Gibraltar range and part of washpool national parks, New South Wales. Cunninghamia, 10, 439-474.

[47]. Ogunjinmi, A. A., Ijeomah, H. M., \& Aiyeloja, A. A. (2009). Socio-economic importance of bamboo (Bambusa vulgaris) in Borgu local government area of Niger State, Nigeria. Journal of Sustainable Development in Africa, 10(4), 284-289.

[48]. Jacobson, S. K., \& Robles, R. (1992). Ecotourism, sustainable development, and conservation education: Development of a tour guide training program in Tortuguero, Costa Rica. Environmental Management, 16(6), 701-713.

[49]. Kleinbaum, D. G., Dietz, K., Gail, M., Klein, M., \& Klein, M. (2002). Logistic regression. New York: Springer-Verlag.

[50]. Kolahi, M., Sakai, T., Moriya, K., Makhdoum, M. F., \& Koyama, L. (2013). Assessment of the effectiveness of protected areas management in Iran: Case study in Khojir National Park. Environmental management, 52(2), 514-530.

[51]. Kontogeorgopoulos, N. (2005). Community-based ecotourism in Phuket and Ao Phangnga, Thailand: Partial victories and bittersweet remedies. Journal of sustainable tourism, 13(1), 4-23.

[52]. Liu, Z. (2003). Sustainable tourism development: A critique. Journal of sustainable tourism, 11(6), 459475.

[53]. Mahony, K., \& Van Zyl, J. (2002). The impacts of tourism investment on rural communities: three case studies in South Africa.Development Southern Africa, 19(1), 83-103.

[54]. Masozera, M. K. (2002). Socioeconomic impact analysis of the conservation of the Nyungwe forest reserve, Rwanda (Doctoral dissertation, University of Gainesville, Florida).

[55]. Mbaiwa, J. E., \& Stronza, A. L. (2011). Changes in resident attitudes towards tourism development and conservation in the Okavango Delta, Botswana. Journal of environmental management, 92(8), 1950-1959.

[56]. McNeely, J. A. (1992). Guidelines: Development of national parks and protected areas for tourism.

[57]. Mensah, I., \& Ernest, A. (2013). Community participation in ecotourism: the case of Bobiri Forest Reserve and butterfly sanctuary in Ashanti Region of Ghana. American Journal of Tourism Management, 2(1), 34-42.
[58]. Millar, J., \& Curtis, A. (1999). Challenging the boundaries of local and scientific knowledge in Australia: Opportunities for social learning in managing temperate upland pastures. Agriculture and human Values, 16(4), 389-399.

[59]. Milner-Gulland, E.J., Bukreeva, O.M., Coulson, T.N., et al. (2003) Reproductive collapse in saiga antelope harems. Nature 422: 135.

[60]. Mitchell, R. E., \& Reid, D. G. (2001). Community integration: Island tourism in Peru. Annals of tourism research, 28(1), 113-139.

[61]. Mugizi, F., Ayorekire, J., \& Obua, J. (2017). Factors that influence local community participation in tourism in Murchison falls conservation area. Journal of Environmental Science and Engineering A, 6(4).

[62]. Nassiuma, D. K. (2000). Survey sampling. Theory and methods, 10(1), 59-63.

[63]. Ngoka, P. C. (2013). Capacity utilization and levels of utilization of tourism potentials of Yankari and Cross River National Parks - Implications for optimistic ecotourism development in Nigeria. African Journal of Hospitality, Leisure and Tourism, 2, 1- 12.

[64]. Ngoufo, R., Yongyeh, N. K., Obioha, E. E., Bobo, K. S., Jimoh, S. O., \& Waltert, M. (2014). Social norms and cultural services-community belief system and use of wildlife products in the Northern periphery of the Korup National Park, South-West Cameroon. Change and Adaptation in SocioEcological Systems, 1(open-issue).

[65]. Jacobson, S. K., \& Robles, R. (1992). Ecotourism, sustainable development, and conservation education: Development of a tour guide training program in Tortuguero, Costa Rica. Environmental Management, 16(6), 701-713.

[66]. Nursey-Bray, M., \& Rist, P. (2009). Co-management and protected area management: Achieving effective management of a contested site, lessons from the Great Barrier Reef World Heritage Area (GBRWHA). Marine Policy, 33(1), 118-127.

[67]. Nuryanti, W. (1996). Heritage and postmodern tourism. Annals of tourism research, 23(2), 249-260.

[68]. Jimoh, S. O., Ikyaagba, E. T., Alarape, A. A., Obioha, E. E., \& Adeyemi, A. A. (2012). The role of traditional laws and taboos in wildlife conservation in the Oban Hill Sector of Cross River National Park (CRNP), Nigeria. Journal of human ecology, 39(3), 209-219.

[69]. Oruonye, E. D., \& Ahmed, M. Y. (2017). Assessment of environmental effect of abandoned uranium mine site in Mika village of Taraba State Nigeria. International Journal of Geography and Geology, 6(4), 70-78.

[70]. Pimbert, M. P., \& Pretty, J. N. (1997). Parks, people and professionals: putting 'participation'into protected area management. Social change and conservation, 16, 297-330.

[71]. Naidoo, P., Ramseook-Munhurrun, P., \& Seegoolam, P. (2011). An assessment of visitor satisfaction with nature-based tourism attractions. International journal of management and marketing research, 4(1), 87-98. 
[72]. Richins, H. (2009). Environmental, cultural, economic and socio-community sustainability: A framework for sustainable tourism in resort destinations. Environment, Development and Sustainability, 11(4), 785-800.

[73]. Kim, S., Park, E., \& Phandanouvong, T. (2014). Barriers to local residents' participation in community-based tourism: Lessons from Houay Kaeng Village in Laos.

[74]. Schulze, Christian \& Waltert, Matthias \& Kessler, P.J.A. \& Pitopang, Ramadanil \& Saleh, Shahabuddin \& Veddeler, \& Leuschner, Christoph \& Mühlenberg, \& Gradstein, S. \& Steffan-Dewenter, Ingolf \& Tscharntke, Teja. (2004). Biodiversity indicator groups of tropical land-use systems: Comparing plants, birds, and insects. Ecological Applications. 14. 1321-1333. 10.1890/02-5409.

[75]. Sebola, M. P., \& Fourie, L. D. W. (2006). Community participation in ecotourism destinations: Maleboho Nature Reserve. WIT Transactions on Ecology and the Environment, 97.

[76]. Sheldon, P. J., \& Abenoja, T. (2001). Resident attitudes in a mature destination: the case of Waikiki. Tourism management, 22(5), 435-443.

[77]. Sinclair-Maragh, G., Gursoy, D., \& Vieregge, M. (2015). Residents' perceptions toward tourism development: A factor-cluster approach. Journal of Destination Marketing \& Management, 4(1), 36-45.

[78]. Scherrer, P., Smith, A., \& Dowling, R. (2009). Expedition cruising in Australia: proactive steps towards change for sustainability. CAUTHE 2009: See Change: Tourism \& Hospitality in a Dynamic World, 233.

[79]. Sommer, V., \& Ross, C. (2011). Exploring and protecting West Africa's primates: the Gashaka Primate Project in context. In Primates of Gashaka (pp. 1-37). Springer, New York, NY.

[80]. Teye, V., Sirakaya, E., \& Sönmez, S. F. (2002). Residents' attitudes toward tourism development. Annals of tourism research, 29(3), 668688.

[81]. Hockings, M., Stolton, S., \& Leverington, F. (2006). Evaluating Effectiveness: A framework for assessing management effectiveness of protected areas. IUCN.

[82]. Geldmann, J., Joppa, L. N., \& Burgess, N. D. (2014). Mapping change in human pressure globally on land and within protected areas. Conservation Biology, 28(6), 1604-1616.

[83]. Tagowa, W. N., \& Buba, U. N. (2012). Emergent strategies for sustainable rural tourism development of Gashaka-Gumti National Park, Nigeria. WIT Transactions on Ecology and The Environment, 161, 27-41.

[84]. Tao, T. C., \& Wall, G. (2009). Tourism as a sustainable livelihood strategy. Tourism management, 30(1), 90-98.

[85]. Timothy, D. J. (1999). Participatory planningA view of tourism in Indonesia. Annals of tourism research, 26(2), 371-391.
[86]. Tosun, C. (2000). Limits to community participation in the tourism development process in developing countries. Tourism management, 21(6), 613-633.

[87]. Hassan, M. R., Ullah, M. M., \& Chowdhury, M. S. A. (2013). Impact of tourism in Bangladesh economy. World, 3(6).

[88]. Yunis, E. 2003. Sustainable tourism and poverty alleviation. World tourism organization, Spain, PP. 14. Retrieved March 10, 2004 from http://www.worldtourism.org. Yunis, E. 2004. Sustainable Tourism and Poverty Alleviation. Paper presented at the World Bank - ABCDE Conference- Europe, PP. 1-8.

[89]. Moscardo G (2015) Building Community Capacity for Tourism Development. Wallingford, UK: Cabi Publications

[90]. Wilson S, Fesenmaier DR, Fesenmaier J, Van ES (2001) Factors of success in rural tourism development. Journal of Travel Research 40(2):132138.

[91]. Zhang, J., Inbakaran, R. J., \& Jackson, M. S. (2006). Understanding community attitudes towards tourism and host-Guest interaction in the urban-rural border region. Tourism geographies, 8(2), 182-204. 